\title{
Chapter 10 \\ Crisis in Solomon Islands: foraging for new directions
}

\author{
Transform Aqorau
}

Solomon Islanders are fed up with the constant politicking and petty bickering of their politicians and the manipulative behaviour of Asian loggers, which has resulted in the corruption of the entire fabric of Solomon Islands society save for the judiciary. Speaking to the former legal adviser to the Department of Forestry recently, I was told that he had grown tired of brown envelopes being handed to him. On one occasion, as he was getting out of his car, a group of Malaysian loggers turned up and - before he could wind the window closed - threw a bundle of neatly folded cash onto the passenger seat. They told him that it was for him to keep. On returning to his office, he told the commissioner, who instructed him to return the money. The legal adviser has since left to work in the Marshall Islands. Just recently, a former government minister (currently a member of the opposition) told me that when he was acting Minister for Mines and Energy, he was asked by a couple of his fellow ministers just before the elections to approve the application of a Chinese prospecting company and they would each be paid SI\$50,000. The minister told me that the elections were closing in, and the two ministers said that the money could help their campaign. When I was legal adviser at the Ministry of Foreign Affairs, I received a call from the prime minister asking whether I could assist in developing drafting instructions for a proposed communications bill. I said that I would be willing to help out and he asked whether I wanted to be paid additional money for the service. I said no, since I was a civil servant and was already being paid by the government. 
If Solomon Islands is to get anywhere, if it is to prosper, if it is to have a secure future, if it is to have a sustainable future with its people enjoying a standard of living that its natural wealth can generate, it must overcomefirst and foremost - the terrible legacy of corruption that has permeated every inch of Solomon Islands society. The corruption that has been spawned largely by Asian logging companies has infiltrated the highest echelons of government and reaches down to the common man on the street. Solomon Islanders have gone berserk over logging, and it is being fuelled largely by the lavish way in which Asian logging companies bribe, cajole and unduly influence Solomon Islanders.

This chapter seeks solutions to the crisis that has beset Solomon Islands. Notwithstanding the presence of the Regional Assistance Mission to Solomon Islands (RAMSI), Solomon Islands still has a long way to go to bring back accountability, transparency and good governance to its institutions. Current conditions of peace and stability are only superficial and there remains deep-seated resentment between former adversaries from Malaita and Guadalcanal. The unfortunate situation in which Asian logging companies have become so powerful is only a small part of the problem. The biggest problems are poverty and social and economic inequities.

This chapter proposes a number of policy options for the Solomon Islands government. These are by no means exhaustive. With the problems that Solomon Islands has experienced, finding solutions has become akin to dragging oneself up from a bottomless pit. The dilemma that the Solomon Islands government faces is where to start: which sector should take priority, should it be education, health, law and order, land review, constitutional restructuring, rural development or provincial government strengthening? The list goes on. This chapter offers some ideas about some areas that can be addressed as a matter of priority. It concludes that Solomon Islands is still foraging for new directions. On the one hand, there is the political rhetoric of Prime Minister Manasseh Sogavare, who often says one thing and does another. On the other hand, there is a lack of resources to do the things that the government wants to do. Solomon Islands is torn between two competing forces: the desire to get on with life, and a lack of resources to establish the basis for this. 


\section{The Asian logging connections}

Logging in Solomon Islands has been well established since colonial days. In the beginning, most logging operations took place on government land, therefore there were none of the issues confronting the industry today. Customary land was preserved for Solomon Islanders. The trees and forests on customary land were well conserved and provided Solomon Islanders with a source of building materials, herbal medicine and other traditional needs, which were met from whatever the forests could provide. Tribal communities were largely undivided and the social ills associated with large-scale logging were unknown.

When logging on government land declined in the early 1980s because of reduced numbers of trees, logging companies started to look at gaining access to customary land areas. At the same time, the Government of Malaysia tightened its laws governing the large-scale exploitation of its forests. This compelled Malaysian logging companies to look offshore to supply their clients. Solomon Islands offered ready prey. Cyclone Namu, which hit a large part of Solomon Islands in May 1986, destroyed much of the country's rice and oil-palm plantations. Solomon Islands' economy was hit hard. The government was, therefore, compelled to pursue other forms of economic development activities and large-scale commercial logging provided an easy alternative.

According to Kabutaulaka (2006), between 1980 and 1983, there was a fourfold increase in the number of logging licences issued to foreign companies. One of the problems of the surge in logging is the perception that it delivers real development to ordinary villagers. I have firsthand experience of the devastating social and environmental impacts of logging and have witnessed the manipulation by Asian logging companies, and the ineptitude of Solomon Islands government officials to stand up to the undue influence that logging company officials can exert. Since 2000, I have made my home in Rakutu, Ziata, which is a good two hours' walk from Munda on the south coast of New Georgia. The island of New Georgia has been the site of some of the most extensive logging operations in Solomon Islands' forestry history. Rakutu is situated in the bush along the Munda-Noro road. Noro hosts two important companies providing much-needed revenue for the coffers of the Solomon Islands government: the Soltai Fishing Company and NFD Fishing Company Limited. Unbeknown to me, a timber rights 
agreement was signed in November 2004 between five trustees - three of whom are closely related to me- and Delta Timber Company to log areas within Kazukuru Left Hand land, including the area where I live. This did not come as a surprise to me because logging is on the minds of almost everyone who has a piece of land. It was, however, saddening because of the inevitable loss of biodiversity in the pristine tropical forest and the fact that people will be poorer, not richer, as a result of logging. Delta is a subsidiary of Earthmovers, one of the largest logging companies in Solomon Islands and owned by Malaysian business interests. Delta Timber Company was established by an employee of Earthmovers and its local consultant, who was also a serving member of parliament at the time of Delta's establishment. The individual concerned is now a minister in the Sogavare government. The association between provincial and national politicians and logging companies makes it very difficult for the government to address the corruption that this industry has caused.

The extraordinary way in which Asian logging companies have permeated almost all levels of Solomon Islands society is illustrated by two cases with which I am acquainted personally. The first is my own futile endeavour to get information from the Department of Forestry and the Western Province government about Delta's operations on Kazukuru Left Hand land. After learning about the agreement, I visited the Forestry Department in Honiara several times and asked to see the relevant file, which would have allowed me to see the terms of the agreement and also see a copy of the licence. The information would have helped inform me about the nature of the operation and determine the legal action I could take against the so-called trustees, the Forestry Department and Delta. I also wrote to the secretary of the Western provincial government to receive confirmation of the minutes of the timber rights hearing, which is required under the Forest Resources and Timber Utilisation Act (Solomon Islands Government 1999: Cap.40).

All my inquiries were, however, in vain and I kept getting all sorts of excuses about the relevant file. I was told that the file was with the commissioner. The next time it was with the minister, and then again it was with the AusAID-funded project personnel. Each time I went to inquire at the forestry department, the file was with someone else, but I was assured that they would find it and make it available. I eventually wrote to the permanent secretary but, like his counterpart in the Western provincial 
government, he deemed me not worth responding to. I did, however, find out from the assistant administrative officer at Munda (the officer responsible for all administrative matters pertaining to the provincial government at Munda) that no timber rights hearing had been convened at Munda in respect of the timber rights granted to Delta. Section 8 of the Forest Resource and Timber Utilisation Act requires the executive of the provincial government to fix a place within the area of its authority and a date - no earlier than two months and no later than three months from the date of receipt of the copy of the application - for a meeting to be held with the appropriate government, the customary landowners and the applicant. The purpose of the meeting is to determine: whether or not the landowners are willing to negotiate for the disposal of their timber rights to the applicant; whether those proposing to grant the timber rights in question are the people, and represent all the people, lawfully entitled to grant such rights and, if not, who such people are; and the nature and extent of the timber rights, if any, to be granted to the applicant. I was also able to subsequently confirm with the principal forestry officer in charge of the Forestry Research Station at Munda that to the best of his knowledge no timber rights hearing had been convened, as was required by law.

Recently, the premier of Malaita Province called for an investigation into all timber rights hearings for logging operations in Malaita. I can only imagine what such an investigation would reveal. What most logging companies have done is bypass the timber rights hearings and simply negotiate directly with so-called landowners. The Forest Resources andTimber Regulations specify that when a timber company negotiates with a community, it must do so 'with the chosen representatives of the landowners in public' and that the negotiations must take place in the presence not only of the landowner's legal adviser but also of representatives of the province and the Forestry Division. If the two sides agree, the agreement is to be signed in the approved form by 'the Company and not less than 5 representatives chosen by the landowners'. One copy of all such agreements must be deposited with the province and one copy with the Forestry Division within 14 days of being signed (Solomon Islands Government 1999).

While this is required under the regulations, it does not negate the requirement under the act to determine the right of those who can grant timber rights. 
The second illustration concerns the influence that logging companies have even over such things as chartering planes for deceased relatives of the trustees. I know of one recent case where relatives who travelled to their home village after the father of a trustee passed away had their costs reimbursed. The company also contributed to the costs of food for those who had gathered in the village for the wake. This same company advanced money to the trustees. Whenever the trustees travel to Honiara, they are put up in hotels. To renovate their church, the trustees advanced money from the company to pay for the renovations. All of these advances are, of course, deducted from the agreed royalty so usually the landowners' proportion paid by the company is far less than what was originally agreed because of the deductions for advances. This story is, of course, repeated everywhere: the same thing happens in every logging concession.

In 1999, the government granted logging company Silvania Ltd permission to establish an oil-palm plantation on government land in Vangunu, New Georgia. Recently, the auditor-general's office issued a scathing report revealing that the oil-palm plantation was merely a disguise to enable the company to log the trees on the land. The company did not have any experience in growing oil palms and had no interest in developing a plantation. This happened under the government of Bartholomew Ulufa' alu.

Solomon Islanders at all levels, from the grass roots right up to the highest echelons of government, have become crazy about logging. It is easy money. The government's reluctance to take drastic measures to address the exploitation of Solomon Islands' forest resources is largely because of its misguided belief that logging contributes significantly to gross domestic product (GDP). It should not be interfered with because that would severely impact on the country's foreign exchange earnings.

Apart from unsustainable log production, another issue that dominated discussions of the forestry industry was Solomon Islands' economic dependence on log exports. In 1990, logging contributed 34.5 per cent of the country's total exports. This increased to 54.9 per cent in 1993. In 1994, it contributed 56 per cent of the country's export earnings and 31 per cent of all government earnings... In the ten years between 1988 and 1998, timber made up a huge percentage of Solomon Islands' principal exports...From 1992 to 1996, receipts from log exports increased dramatically and dominated total exports. The average value of timber 
exports in that period was SI\$285.2 million per annum. In 1998, however, there was a dramatic decline in log export receipts: SI\$196.3 million as compared to SI\$290.7 million in 1997 and an average of SI\$285.2 million in the period from 1993 to $1996 \ldots$ The 1997 and 1998 declines were due to the fall in export prices and volume as a result of the continued adverse developments associated with the Asian financial crisis. Despite this decline, the value of log exports was still well above that of other commodities (Kabutaulaka 2007:247).

The behaviour and practices of Asian logging companies have not helped make the situation any better. In a penetrating analysis of how the government and politicians have exacerbated the problem, Tony Hughes (2004) argues

[a]t the same time successive governments were making a famous mess of the arrangements for promoting and monitoring foreign direct investment in [Solomon Islands]. The process was heavily politicised from the start, with ministerial and prime ministerial involvement in interviewing and selection of investors and devising of investment conditions, with some of the more important and personal conditions apparently not being recorded. This long-winded and corruption-prone process has had a deterrent effect on a number of genuine would-be investors, some of whom have made their feelings known in Honiara, and has encouraged some obvious con-artists to try hijacking parts of the economy. Amazing statistics have periodically appeared about the number and value of incoming investments approved, but there has never been any serious attempt to follow [these] up to see what actually happened and publish the information.

The problem is not just how politicians manipulate the system. I also blame the self-interest of Asian logging companies. Just before the prime ministerial election in April 2006, Sean Dorney of Radio Australia interviewed Charles Dausabea, the Member for East Honiara. I heard the interview on Radio Australia. Dorney described Dausabea as a linchpin of Solomon Islands politics. I disagreed and wrote a letter to the Solomon Star newspaper (Aqorau 2006). It was aimed largely at the Asian logging companies and their role in making and breaking governments in Solomon Islands. The letter stated in part that

...the real linchpins in Solomon Islands politics are actually unelected. They are already busy manipulating the process, if not explicitly, at least 
implicitly. The full-page advertisement that appeared in Monday's Solomon Star is evident [sic] of the undercurrents already at play. There are also some fairly well known power broker(s) lurking in the background somewhere, seemingly oblivious to the situation, but certainly strenuously working in the background to influence next Tuesday's election results. There are possibly some very powerful entities who could potentially lose considerable leverage and advantage also working tirelessly at influencing the outcome so that they can continue to maintain their preferential status. The machinations of their operations are fairly well known. They are not elected and represent only their narrow interests which they will want to pursue through the outcome they are endeavouring to influence. These are the real linchpins and not, with respect, Hon. Charles Dausabea as alluded [to] by the media. With respect, [Dausabea] being himself as everyone who knows him, will lobby, will endeavour to form alliances, will make media statements, and will ostensibly appear as the power broker, but with further respect, his is a spent force, lacking the potency he once yielded, and certainly not as powerful as the unseen forces working in the background (Aqorau 2006).

Solomon Islanders confront many challenges. One of the biggest challenges facing the Sogavare government is restoring public confidence in the light of the total breakdown of government structures, institutions and processes. The Sogavare government has been making the right noises about transparency, good governance and accountability, but so far, Solomon Islanders have not seen any evidence of real progress on this front. Indeed, Sogavare himself has demonstrated dictatorial tendencies. Firstly, he took on the Director of Public Prosecutions (DPP) and accused the DPP and the judiciary of colluding to keep two politicians who were arrested after the April riots in custody longer than necessary. Secondly, he appointed the secretary to cabinet without advertising the position, and advertised for the positions of permanent secretaries but hand-picked them nevertheless. Third, he established a commission of inquiry into the April unrest to be headed by a retired Australian judge, who is himself under investigation. He also included in the terms of reference of the commission an investigation into whether the arrest and prosecution of the two politicians were politically motivated. At the time of writing, he was embroiled in a public disagreement with the attorney-general about the latter's application to the High Court to strike out the two controversial terms of reference relating 
to the circumstances of the politicians' arrests because the matter was the subject of court proceedings. Prime Minister Sogavare threatened to sack the attorney-general and replace him with a private lawyer from Australia, who is known to have political connections in Solomon Islands. (This is what subsequently occurred. See Chapter 1.) All this talk about good governance is at the moment just that — all talk and no action.

Foraging for new directions: is there a way forward?

The scenes of rioting in Honiara in April 2006 were broadcast around the world. Now when I meet people and tell them about Solomon Islands, they know where it is because of the publicity the riots received. I listened to the reports on the radio and to analysis from various academics from Australia, New Zealand and Fiji. Funnily enough, there were not as many Solomon Islanders interviewed as there were Australians and New Zealanders.

I have often been bothered by the fact that Solomon Islands is a rich country, yet it is so undeveloped. It is true that being rich in natural resources does not necessarily translate into social and economic wealth; there must be political stability as well as an educated population. I think of the case of Oman, which, 30 years ago, had only three miles of paved road. Today, all its roads are paved. Although its sultan is very wealthy because of his country's oil, he has ensured that his people also improve their social and economic well-being. I have often pondered what could have happened in Solomon Islands.

As legal adviser to the Pacific Islands Forum Secretariat in 2003, I had the unique privilege of attending the forum's foreign affairs ministers' meeting in Sydney on 30 June. It was touching to hear the support and sympathy for Solomon Islands from regional leaders. They had gathered there under the auspices of the Biketawa Declaration, which allowed the forum to lend whatever support was necessary to assist a for um member. RAMSI was born out of this meeting. Having listened to the discussions in Sydney, I viewed RAMSI as the conduit through which Solomon Islanders could rebuild their shattered and war-torn country. The region was giving Solomon Islands a second chance. That opportunity, however, cannot be dependent on RAMSI. The responsibility to rebuild Solomon Islands, to re-establish its institutions and restore confidence in the country rests ultimately with Solomon Islanders. Only Solomon Islanders can rebuild their country. 
As I watched and listened to events unfold from Suva, I began to see some worrying trends. These were reconfirmed when I returned to work in Solomon Islands. My major worry was that our political leaders would not use the opportunity afforded by RAMSI to put in place policies that would ensure Solomon Islands did not repeat the problems that resulted in the ethnic tensions. There was an almost total lack of direction as to where the country was heading. I have not changed my views about RAMSI in spite of criticisms about its response — or lack thereof — to the April 2006 riots. In an article on local perspectives of RAMSI, Matthew Allen argues that

...the RAMSI of 'state building' and 'nation building' is markedly different to the RAMSI which is seen and interpreted by Solomon Islanders. For the majority of people in Solomon Islands RAMSI means police and soldiers. Moreover, it is widely perceived as an Australian dominated enterprise, composed mostly of Australian security forces which are commanded by Australian officers (Allen 2006:199).

With respect, RAMSI cannot and never will be able to nation build and state build in Solomon Islands; only Solomon Islanders can legitimately and realistically do that. The onus is on Solomon Islanders and not on RAMSI to rebuild Solomon Islands. RAMSI, however, offers Solomon Islanders and its political leaders an easy target to blame for their own failures. I do not want to be construed as an apologist for RAMSI, but Solomon Islanders cannot just sit back, lament and complain about the inequities between their salaries and those received by RAMSI-supported personnel holding line positions without saying openly: this is what we want Solomon Islands to be in 50 years, and we will achieve it with RAMSI's support.

In the period leading up to the April 2006 general elections, I wrote an article that set out some of the critical issues that had to be handled by the incoming government. I wanted a broader readership in Solomon Islands to read my thoughts and I also wanted to participate in a debate about what issues should be addressed by the new government, so I sent the article to the Solomon Star. It was never published, so I sent it to Islands Business magazine. In the article, I argued that the Kemakeza government had been provided with an environment through the support of RAMSI in which to govern effectively. The two and half year time frame that the Kemakeza government had after the arrival of RAMSI was only long enough, in my view, for it to 
address governance structures and law and order issues. I argued that if it had attempted to address the underlying social and economic problems that had beset Solomon Islands in the past 27 years, it was not apparent.

The Sogavare government has announced that it will pursue rural development as one of its key policy priorities. Rural development without any infrastructure support to spur it will be hard to achieve. There remain, however, some very serious issues that the government needs to address. I have set these out without making any claim as to whether they are the only issues that need to be addressed. I like to think that Solomon Islands' problems are like falling into a bottomless pit: it is very hard to begin climbing out until you have hit the bottom. This is perhaps Solomon Islands' last opportunity to re-establish itself. The current members of parliament have only the next four years to lay a foundation on which to build Solomon Islands' prosperity.

The omens, however, are not good. Prime Minister Sogavare has already found himself in all sorts of self-inflicted disputes. He has made several contradictory statements, and seems bent on undermining the independence of the three arms of government. Already his government is unstable, with the recent sacking of his Minister for Commerce and former prime minister, Francis Billy Hilly. Six of his ministers have also resigned from the National Party. The signs are fairly ominous that Sogavare's government might not see out its full four-year term. Nonetheless, the challenges facing Solomon Islands remain, irrespective of who is in government. I set these challenges out below, as well as suggesting ways in which Solomon Islands can move forward. So what are some of these challenges? One of the biggest challenges facing Solomon Islands today is overcoming corruption and the influence of Asian logging companies, in particular, the negative influence this has had on the mind-set of ordinary villagers and government officials. The hand-out mentality that it has spawned and the idea that logging is the panacea for Solomon Islands' economic problems needs to be debunked. Solutions are not easy to come by. This is because government ministers, senior public servants, provincial politicians, village chiefs, community leaders, lawyers and ordinary villagers all have a stake in logging.

The other challenges pertain to addressing the underlying causes of the ethnic tension and Solomon Islands' rapid population growth. 


\section{Underlying causes of ethnic tension not addressed}

The social, political and economic factors that led to the ethnic tension and quasi-civil war have not been addressed. There should not be any pretence that all is well in Solomon Islands now that law and order has been restored, justice is being delivered and the Gold Ridge mine and oil-palm plantations are being revitalised. There are serious undercurrents simmering and feelings of mistrust that still exist among the former warring parties. If these undercurrents are not addressed, they could easily reignite the tension. It is common knowledge that not all the high-powered guns used in the conflict were collected by RAMSI. The notorious Edmond Sae is still at large and it is alleged that he and others hiding with him still have such weapons. After the rioting and immediately before the convening of parliament at which Sogavare was elected, Honiara was rife with rumours that Sae and his group from the 'bush' were hiding in the settlements on the outskirts of Honiara. Their mission (according to the rumours) was to ensure that Snyder Rini stepped down and to take on the military component of RAMSI. In light of the fact that guns are still in the community, such rumours have the potential to create instability. There are always rumours that once RAMSI leaves, the conflict will start again.

Much has been said about the economy and the confidence brought about by the restoration of law and order. The April riots severely shattered that momentum. Even before the riots, however, things were generally not what they were made out to be. The fire that burnt down the new oil-palm plantation headquarters early in 2006, the calls for greater resource-owner participation in the Gold Ridge mine and the demands for alienated land in Lunga and Tenaru to revert to the original landowners were evidence of the tensions that still existed. The only reason these issues have not resulted in violent confrontation is because of the presence of RAMSI. The proliferation of squatters in Honiara needs to be addressed. One cannot help but notice the exponential growth of unemployed people loitering in the town since the beginning of the year. There are now more squatters in the national capital than there were before the tension. What is more worrying is the encroachment of these squatter settlements on customary land just outside Honiara. Something must be done about rural development. The development of Malaita, in particular, is an important part of the longterm solution of some of the problems facing Solomon Islands. Naturally, 
because of its larger population and underdevelopment, Malaita supplies a greater proportion of people migrating to Honiara than other islands. This is in no way meant to be an indictment of Malaitans; it is simply stating a fact. What it means for the Sogavare government is that the Auluta oil-palm plantation, the Bina Harbour project and an international runway for Malaita must be pursued with vigour. It also means that land and resource owners from Malaita must be amenable to the idea that if they are to develop, they must allow their resources to be developed. This is true not only for Malaita; it is true for everyone else. It means that approaches to economic development must be different from what they have been in the past 27 years since Solomon Islands gained independence.

\section{Rapid population growth}

Solomon Islands' population continues to grow at an alarming rate. It has one of the highest population growth rates in the world, which has serious implications for society. The effects of rapid population growth are quite visible in the areas of public health and education. Visitors will immediately notice the stench and filth of betel-nut stains and the piles of rubbish outside residential and commercial buildings in Honiara. Solomon Islands' capital provides a good illustration of the public health problems arising from the population explosion. There is generally poor sanitation and drainage, with the dusty and dirty general environment not conducive to healthy living. HIV / AIDS is also another threat that will have to be addressed with greater political vigour than has hitherto been the case. In education, the annual increase in the number of children attending school is obvious. There is overcrowding in schools, which generally are also under-resourced. Such an environment is not conducive to learning. There is also increasing poverty, especially in Honiara. Poverty fuels other social problems, such as petty stealing, ravaging in garbage dumps and prostitution.

It is not possible in a short discussion such as this to describe all the challenges facing Solomon Islands. I have often thought that there are so many challenges that one problem is knowing where to start. The key challenge, of course, is choosing a path that will avoid a repeat of the ethnic tension. Once again, I do not claim to have a monopoly on knowledge about what should be done. The following ideas are simply that - ideas about issues that should receive the government's attention 
- establish a royal commission into the ethnic tension

- establish, as a matter of urgency, a commission of inquiry into land matters

- establish an appropriate population policy

- decentralisation of development projects

- raise education standards

- healthy environment

- free the public service of political interference

- address the fluidity of electioneering and politicking

- make it unlawful for members to switch political parties once elected

- introduce limited preferential voting

- make illegal the giving of gifts, money, airfares, assistance and demands for money within six months of an election

- find an alternative way of electing the prime minister

- enhance the role of the media.

Establish a royal commission into the ethnic tension. I have always felt that Solomon Islands' political leaders had something to hide, that they wanted memories of the ethnic tension to be swept under the carpet. The danger of such an approach is that we will never really know the full extent of the involvement of various individuals, including national and provincial politicians, and we will never understand fully the reasons for groups taking up arms. How can Solomon Islands be expected to move on without ensuring that the reasons for the ethnic tension have been addressed? The victims of the tension are still calling on the government for compensation. If nothing is done to understand and address the causes of the ethnic tension, it is possible that it will happen again. It is also dangerous to simply forget about it. The nation needs to know who planned and masterminded the ethnic tension. Those who tragically lost their lives should not be nameless victims of violence perpetrated by a few who held the entire nation to ransom.

Establish, as a matter of urgency, a commission of inquiry into land matters. The outgoing Minister for Lands in the Kemakeza government announced the establishment of a commission of inquiry into 
land matters, but so far nothing has been done towards the creation of such a commission. Addressing problems of land tenure in Solomon Islands must be among the top priorities of the government. I believe that there is already a class of essentially landless Solomon Islanders. I say so, however, with some qualification, but there are people for whom returning to their ancestral land is no longer an option. This must be recognised. During the ethnic tension, many people were compelled to return to their ancestral land. Some of them had not been back since they were born. Initially, they were welcomed, but many of them were later forced to leave and return to Honiara because - having been away for a long time - their rights to land had diminished. The proliferation of squatters in and around Honiara attests to this. Sadly, many of these settlements are not serviced by proper public utilities - roads, water, electricity and telecommunications - creating a distinct class of citizens in Honiara deprived of the most basic services. The issue of squatters is sensitive and needs to be handled carefully. Having said that, I do not believe the government should shy away from it, hoping that it will just disappear. It won't - and left alone, it could be the trigger for further ethnic tension.

The need for a population policy. Solomon Islands' rapid population growth needs to be addressed through the development of a population policy that encourages smaller-sized families. The traditional idea that larger families mean more hands to provide labour is no longer valid. In fact, the converse is now true because the main struggle people face is finding the money to pay their children's school fees. In my village these days, it is almost not worthwhile celebrating a birthday because if you do have a party there are usually many more children than there is available food. While I do not advocate the birth-control methods used in China, I would suggest that the government could aim, as a matter of policy, to reduce the population growth rate by half over a defined period of time, say 20 years.

Decentralisation of development projects. One of the pillars of the Sogavare government is rural development. It was on this basis that Dr John Roughan was appointed secretary to cabinet so that he could spearhead the government's new development strategy. Roughan was director of the Solomon Islands Development Trust (SIDT), which worked for a long time to empower villagers. The test for the government is whether any new major development projects will be diverted to the provinces. What is 
sorely needed is infrastructure such as roads, bridges, telecommunications, wharfs and ports to spawn development. Two international-standard airport runways should be built in Western and Malaita provinces. The ethnic tension clearly showed the danger of centralising government functions in one location. With international-standard facilities in the provinces, Honiara could be divested of its primacy as the 'bright lights' of Solomon Islands and thereby reduce the inward migration of people to Honiara.

Raising education standards. I have also advocated the importance of education for providing better opportunities. The government should ensure education standards are raised to a level whereby Solomon Islanders can export their skills rather than cheap raw materials that damage the environment. In the past 10 years, the number of schools has increased but the number of qualified teachers has not matched this. The large number of untrained teachers in many schools throughout Solomon Islands has affected the quality of education. Education is a three-legged partnership between parents, students and teachers, whereby students should be taught to be creative, critical and thought provoking and not just to regurgitate what teachers/lecturers tell them. Too often students, including university students, lack creative, critical thinking abilities.

Healthy environment. The health of the environment is fundamental. The government and every Solomon Islander should ensure that Solomon Islands has a clean, healthy environment. In addition to the beautification of Honiara and villages throughout the country, a greening of Solomon Islands policy should be adopted by the government whereby every household, suburb, village and town is encouraged to plant trees, not just for beautification but to help the environment.

Freeing the public service of political interference. In the past 15 years, the politicisation of the public service has led to a lowering of standards within it. The government should ensure that the public service is free of political influence. The public service plays an important role in the fabric of Solomon Islands society. One of the first things the government should do is change the nomenclature 'permanent secretary' because there is nothing permanent about the position. A problem facing the public service is a lack of capacity in policy implementation, especially through legislating to implement government policy. This is evident by the extremely small amount of legislation that parliament has enacted in the past four years. This 
problem will, unfortunately, be compounded in the next few years because of the capacity gaps that now exist in the service. Having said that, I should point out that a number of very positive developments have taken place in the past three years. There are well-publicised manuals on the Solomon Islands People First Network's web site on various procedures, including the role of permanent secretaries, how to make legislation and the role of cabinet. These manuals are very useful tools that should enhance the capacity of the public service.

\section{Addressing the fluidity of electioneering and politicking. Perhaps} Solomon Islands' biggest problem is political instability. Electoral laws should be amended so that elections are contested only by political parties and not by independent candidates. This would eliminate the uncertainty of individuals standing with no particular political platform or policies. The counter-argument is that political parties have never worked, do not have a strong grass roots base, have no particular ideological leanings and, historically, once elected, parliamentarians have oscillated from one side of the house to the other. Greater political stability is needed so that Solomon Islands can have a secure future and this should be the overriding public policy concern. It would be better for Solomon Islands to have a grouping within parliament that already had its policies and strategies in place once elected, rather than a group that started to think about its policies and strategies only after forming government. We also need to move forward rather than being constrained by the uncertainties of the present system.

The idea of electing parties rather than individuals is certainly not new and can be found in a number of countries throughout the Commonwealth. It could be argued that Solomon Islanders are not yet ready for the election of parties because of the wantok system, low levels of understanding of government and the electoral processes. My response is that we need to start somewhere. The suggestion that Solomon Islanders are not sophisticated enough to appreciate a strong party system has two implications: firstly, Solomon Islanders are not intelligent and flexible enough to understand and accept change; secondly, it is best that Solomon Islanders be condemned to the same old uncertain, inherently weak system that we currently have. Most Solomon Islanders would be only too happy to see change that would realise greater political stability. The key to economic growth and greater social and economic well-being is political stability. 


\section{Making it unlawful for members to switch parties once elected.} Logically, it follows that if individuals are to be elected on the basis of their party affiliation, they should remain loyal to the principles, policies and strategies espoused by their party. Therefore, the electoral laws should be amended to make it unlawful for any person who has been elected to parliament as a member of one party to switch to another party. The counterargument is that it would be hard to discipline parliamentarians and such a law would simply not work. My response is that there is an overriding public policy interest in ensuring stability, reducing fluidity and tightening discipline in the national parliament, which necessitates such change. Ensuring that the sanctions and penalties were high would be incentive enough for members not to change parties after they were elected. The system is applied in some countries in the Commonwealth - for example, Papua New Guinea - and could be tried in Solomon Islands as a means of addressing the problem of members frequently crossing the floor and thereby creating instability.

Introducing limited preferential voting. The first-past-the-post system of voting does not result in a democratically elected member who is truly representative of the electorate. In the just-completed national elections, only two members were elected with more than 50 per cent of the votes cast. The election of the prime minister, on the other hand, requires that the winner must obtain at least 51 per cent of the votes. Electoral laws should be changed to ensure parity in the general principles underpinning the majority required to elect a prime minister and MPs. Introducing limited preferential voting whereby voters have a choice of up to three people can do this. If a candidate receives more than 50 per cent of the votes cast on the first count, he/she wins. If, however, no one wins an outright majority, the preferences are distributed until such time as a candidate receives more than 50 per cent of the votes. The counter-argument is that such a system is complicated, will confuse voters and it will take too long to count votes. My response is that there is a strong public policy interest in ensuring that a truly democratic parliament is elected, which represents the majority of Solomon Islanders; it is also something that is being implemented in Papua New Guinea.

While such a system would not eliminate bribery and vote buying, it would certainly reduce these practices, because voters would at least have more than one choice. The introduction of a limited preferential system can be phased in through provincial assembly elections and eventually the 
national elections. It is instructive to note that the introduction of the single ballot box system generated considerable debate in parliament. Indeed, there were suggestions that Solomon Islanders were not literate enough to understand this system. I think it is a fair observation that such comments were generated largely by fear among some leaders that any change to the system might lesson their chances of winning. I would argue that the main consideration should be the national interest - stability and ensuring elected representatives receive more than 50 per cent of the votes - rather than the narrow, self-centred interests of MPs. The idea is not new and is applied in countries throughout the Commonwealth, including the Pacific Island Forum countries. In fact, in 1995, I made submissions to the Electoral Review Committee to introduce a limited preferential voting system. I reiterated those same sentiments in the Solomon Star in 1998.

Making illegal the giving of gifts, money, airfares, assistance and demands for money within six months of an election. My observation of the general elections is that they are becoming more corrupt and routinely involve the exchange of goods and services. Voters have also exacerbated the problem by imposing all manner of demands on candidates. The tendency for voters to ask candidates for money, sea fares and airfares, food and school fees during the period leading up to elections has become progressively worse. The 2006 election was one of the most unclean in terms of the attitudes of the voters and candidates. The movement of supporters from one candidate to another depending on who gave them money was not obvious to the casual observer, but was an open secret in the constituencies. There is an overwhelming public policy interest in ensuring that election campaigns are conducted cleanly and fairly on a level playing field.

To ensure that money, goods and services are not transferred between candidates and voters, and to ensure that voters do not impose undue pressure on candidates by demanding money from them, the provisions on bribery and treatment under the National Parliament Electoral Provisions Act and the local government regulations should be made more specific by proscribing altogether any exchange of money, goods or services and voter demands up to six months before elections. As it is, the current laws require proof that such exchanges of goods and services are intended to induce a person to vote. The problem is that it is difficult to determine whether the distribution of water tanks and other forms of assistance a few weeks 
before an election constitute 'development assistance' or 'special treatment' . Perfectly legitimate arguments can be developed either way.

The counter-argument is that such a law is unduly prohibitive and would prevent MPs providing legitimate assistance to their constituents. My response is that the best form of assistance that MPs can offer is to deliver laws that will enhance the social and economic welfare of the people of the Solomon Islands. There is an overriding public policy interest for MPs to discharge their duties as parliamentarians rather than be bankers underwriting school fees, airfares, sea fares, plane charters and so on for their constituents, and in ensuring that elections are a time when issues affecting the social and economic well-being of Solomon Islanders are debated. It should not be a time when the greed, graft and cunning of voters and candidates are manifested so blatantly. Voters must not use the election campaign period as a pretext to milk candidates of whatever money they have set aside for their campaign. Even with tight laws in place, it is difficult to control the exchange of goods and services. The prohibitions should, therefore, be made broader so that they cover any form of exchange of goods and services six months before an election.

Finding an alternative way of electing the prime minister. It is said that the real politicking starts once elected members arrive in Honiara to choose the prime minister. Indeed, if one has been observing the election of prime ministers since independence, it might be fair to say that elected members have become more immature, irresponsible, childish, irrational and militant in their approach to the election of the prime minister. It is almost laughable the way that individual members are literally hijacked by the different groups. The MPs might not realise it, but to the members of the public, such behaviour is tantamount to lunacy.

Black Tuesday — as the April 2006 riots became known — underscored the need to find a more sensible, transparent, accountable and less divisive way of electing a prime minister. The reforms suggested above are a precondition for the proposals for choosing the prime minister. A couple of models are offered. Once again, these models are not new and exist within the Commonwealth, including Pacific Islands Forum countries. The first alternative would be for the head of state to invite the leader of the party or alliance of parties that commands the majority of MPs to form government. This would immediately address the hanky-panky that currently 
occurs. Fundamental to this, of course, is the strong representation of parties in parliament. The second alternative is for MPs to nominate two candidates — or such numbers as appropriate — and have them elected by the people of Solomon Islands. The public policy interest is to find a more stable and cohesive way of electing the prime minister. This would not necessarily eliminate the need for horse-trading, but it would certainly minimise the uncertainties in the present system and ensure a more transparent, accountable and cohesive way of choosing the prime minister.

Enhancing the role of the media. One of the major contributors to a free society is media freedom. Much has been said about the role of the media in Solomon Islands and it is not my intention, therefore, to go through what has been hammered home on several occasions. I was, however, disappointed with the media coverage during the April riots. In emails exchanged with Ofani Eremae, editor of the Solomon Star, after the April riots, I wrote that

...the media has a very important role to play in not only rebuilding the nation, [but in] galvanising public views on what could be incorporated into public policy. My views are only just one of the views that can be put across, but the most important thing in my mind are [sic] the views of ordinary Solomon Islands [sic] and how they will be affected. I don't want the exchange of views to become élitist only because some people can express themselves clearer than others. The important lesson that should be taken from this is that we should also learn to listen, and listen even more.

In terms of the media, I know that there are limits to what the print media can do, but the real reach out [sic] is the SIBC [Solomon Islands Broadcasting Corporation] radio and I think they have failed. Yesterday I listened to your panel discussion through Radio Australia which was excellent, but I cannot understand why SIBC cannot be doing the same, and asking people questions, and searching for solutions. There is far too much music being played on the national broadcast service and not enough educational material from which we can learn. I really want to see a lot of pressure being put on politicians... [to] improve the connection between them and us, and the media must ensure that this happens over the next four years otherwise these 50 people will ruin [the lives of] the 450,000 who live here. Your coverage has been good and I understand perfectly 
the limits that you have. I think that one piece of investigative journalism a month will go a long way to exposing corruption and keeping leaders on their toes (author correspondence with Ofani Eremae, 28 April 2006).

\section{Conclusion}

One of the things I noticed immediately after the October 2000 cease-fire was that people were enthusiastic about rebuilding the country. They were desperate to find any form of work. During that time, I said that there was renewed energy to rebuild Solomon Islands from the ashes. I cannot speak for other provinces, but during that time I observed that people from my area in Western Province did not wait for government hand-outs in order to do something. Many people got into growing tree crops. It was also at this time that I built my own home in the bush - growing a small teak plantation, as well planting nail-nut trees, betel-nut and sago palm. I decided that there was no future in Honiara and that the ethnic tensions had taught Solomon Islanders some important lessons: it reaffirmed the importance of land and it demonstrated that you could not live on someone else's land. The Sogavare government's emphasis on rural development should be welcomed; however, it is easier said than done. Development cannot happen if Solomon Islanders expect others to do it. There has been a lot of criticism of RAMSI, but it is not for RAMSI to nation build in Solomon Islands. Just like the unrealistic expectations that Solomon Islanders have placed on RAMSI, there are unrealistic expectations that others will help Solomon Islands solve all its problems.

Corruption, graft, cunning, uncertainty and so on cannot be totally eradicated; they can, however, be minimised. The ideas offered above will certainly go a long way towards addressing some of the uncertainties in the current system. To those who would oppose change to the current system, I say: traditions, cultures and societal values change over time. While laws are intended to be forward looking, they become outdated, obsolete and inappropriate. That is why they should be changed to reflect how society has transformed. I would argue very strongly that the democratic processes espoused in the 1978 constitution and the National Elections Provisions Act are outdated and need to be changed. I would also question the moral authority of a democratic process that results in the looting, destruction 
and dislocation of Solomon Islands in a way that has never been seen before in the short history of this nation. If MPs are to raise their heads above the destruction, they must change the laws immediately. The test of whether parliament is interested in avoiding another Black Tuesday will be whether the legislative changes proposed above are deliberated on and enacted during the next four years. Failure to do so will be a clear demonstration that our political leaders do not have the national interests of Solomon Islands at heart.

Recently, a minister in the Sogavare government bought a car from a colleague of mine. When the cheque for the purchase of the car was delivered, the drawer was a Chinese shop owner. This was immediately after the April riots. Is there a way out of the crisis? I would argue that there is, but we are still foraging for it.

\section{Acknowledgment}

The views expressed in this article are the personal views of the author.

\section{References}

Allen, M.G., 2006. 'Dissenting voices: local perspectives on the Regional Assistance Mission to Solomon Islands', Pacific Economic Bulletin, 21(2):194-201.

Aqorau, T., 2006. 'The real linchpins of Solomon Islands politics', Letter to the Editor, Solomon Star, 14 April.

Hughes, A., 2004. The economy: past experiences, recent situation and pressing issues, paper presented at the Beyond Intervention: Navigating Solomon Islands' Future Conference, East-West Center-PIDP Workshop, Honiara, 14-16 June.

Kabutaulaka, T.T., 2007. 'Global capital and local ownership in Solomon Islands' forestry industry', in Stewart Firth (ed.), Globalisationa dn Governance in the Pacific Islands, ANU E Press, The Australian National University, Canberra:239-57. Available from http:/ / epress.anu.edu. au/ssgm/global_gov/pdf/ch12.pdf (accessed 28 January 2007).

Solomon Islands Government, 1999. 'Forest Resources and Timber Utilisation Act', The Revised Laws of Solomon Islands, Solomon Islands Government, Honiara. 